\title{
Griseofulvin Efficiently Induces Apoptosis in In Vitro Treatment of Lymphoma and Multiple Myeloma
}

\author{
LEONARD CHRISTOPHER SCHMEEL ${ }^{1,2}$, FREDERIC CARSTEN SCHMEEL ${ }^{1,2}$, \\ YOUNG KIM ${ }^{2}$, SABINE BLAUM-FEDER ${ }^{2}$ and INGO G.H. SCHMIDT-WOLF ${ }^{2}$ \\ ${ }^{1}$ Department of Radiology and Radiation Oncology, University Hospital Bonn, Bonn, Germany; \\ ${ }^{2}$ Center for Integrated Oncology (CIO), Medical Clinic and Polyclinic III, \\ University Hospital Bonn, Bonn, Germany
}

\begin{abstract}
Background/Aim: Recent innovations in the development of systemic and targeted therapies have improved survival and quality of life in multiple myeloma (MM) patients. However, in most cases, this hematological malignancy of monoclonal B-lymphocytes remains incurable. Exaggerated Wnt/ $\beta$-catenin signaling has been demonstrated in lymphoma and $M M$, therefore targeting related signaling molecules might represent a promising therapy approach. Griseofulvin, a widely used antifungal drug, is chemically related to other known Wnt-inhibitors and we recently demonstrated its potent in vivo efficacy in a murine myeloma model. Materials and Methods: The anti-tumor apoptotic effect of griseofulvin at doses ranging from 0.1-200 $\mu \mathrm{M}$ was investigated on a total of ten human and two murine myeloma/lymphoma cell lines, as determined by 3'3dihexyloxacarbocyanine iodide (DiOC6) and propidium iodide (PI) staining in flow cytometry. Results: Griseofulvin significantly induced apoptosis in all investigated myeloma and lymphoma cell lines in a dose-dependent manner, while healthy control cells were less sensitive. Conclusion: Given the known safety profile and apoptosis induction at low effective doses, our data warrant further in vitro and in vivo studies utilizing griseofulvin as a potential therapy agent for MM and lymphoma.
\end{abstract}

Multiple myeloma (MM) represents a hematological neoplasm characterized by monoclonal malignant secretory plasma cells in the bone marrow and is commonly

Correspondence to: Prof. Dr. med. Ingo G.H. Schmidt-Wolf, University Hospital Bonn, Center for Integrated Oncology (CIO), Sigmund-Freud-Straße 25, 53105 Bonn, Germany. Tel: +49 22828717050, Fax: +49 2282879080059, e-mail: Ingo.SchmidtWolf@ukb.uni-bonn.de

Key Words: Griseofulvin, apoptosis, multiple myeloma, lymphoma, therapy, Wnt. accompanied by monoclonal protein in peripheral blood and/or urine $(1,2)$. Innovative therapy strategies, including immunomodulatory drugs (IMiDs) like bortezomib, lenalidomide and thalidomide improve both treatment outcome and patient survival. Also cell-based therapies have been proven to be feasible and effective in initial clinical trials $(3,4)$. However, despite recent innovations, sustainable treatment strategies are still indispensable since the majority of patients might eventually experience relapse of disease.

The activation of the Wnt pathway, usually restricted to embryonic development, represents a tumor-specific signaling pathway and has been shown to induce and maintain oncogenic effects, particularly in the oncogenesis and promotion of lymphoma and MM (5-14). Hence, a specific inhibition of Wnt signaling suppresses tumor progression and, thereby, renders Wnt signaling molecules an interesting therapeutic target for MM $(14,15)$.

Our recent studies confirmed the in vitro and in vivo efficacy of several agents by targeting Wnt/beta-catenin signaling molecules, especially in hematopoietic types of cancer (16-30). Griseofulvin, as the investigated drug, is chemically related to other known Wnt inhibitors and has already shown anticarcinogenic properties in vivo (31). Here, we demonstrated in vitro treatment efficacy and selective induction of apoptosis by griseofulvin in a broad range of myeloma and lymphoma cells.

\section{Materials and Methods}

Cell lines and culture conditions. Cell lines were obtained from DSMZ (Braunschweig, Germany) or ATCC (LGC Standards, Wesel, Germany) and incubated at $37^{\circ} \mathrm{C}$ with $5 \% \mathrm{CO}_{2}$ at $90 \%$ humidity.

The human myeloma cell lines KMS 18, OPM-2, RPMI-8226 and U-266 (all obtained from DMSZ) were cultured in RPMI-1640medium (PAA, Pasching, Austria), supplemented with 5\% heatinactivated fetal calf serum (FCS; Invitrogen, Darmstadt, Germany) and $1 \%$ penicillin-streptomycin (Seromed, Jülich, Germany). Human lymphoma cell lines Raji, SU-DHL-4, Oci Ly 8 Lam 53 and primary chronic lymphocytic leukemia (CLL) cells were cultured 
under identical conditions as human myeloma cell lines. MPC-11 is a murine plasmocytoma cell line and RAW 264.7 is a leukemia monocyte macrophage cell line. Cells were cultured in RPMI-1640 medium supplemented with $5 \%$ heat-inactivated FCS and $1 \%$ penicillin/streptomycin. RAW 264.7 cells were harvested by using $0.05 \%$ trypsin-EDTA solution (Invitrogen).

The human colon fibroblast cell line CCD-18Co was obtained from ATCC (LGC Standards) and cultured in ATCC-formulated Eagle's minimum essential medium (LGC Standards) supplemented with $15 \%$ of heat-inactivated FCS and $1 \%$ penicillin-streptomycin. Cells were harvested by $0.05 \%$ trypsin-EDTA solution (Invitrogen), centrifuged at $1,200 \times g$ for $7 \mathrm{~min}$ and re-suspended in $1 \mathrm{ml}$ media to define the cell count. Media were renewed at least every 3 days.

Human samples. Peripheral blood lymphocytes (PBLs) were isolated from blood samples of healthy volunteers using Ficoll density gradient centrifugation (Lymphoprep; Nycomed, Oslo, Norway). Blood from buffy coats was diluted 1:2 with phosphate-buffered saline (PBS) $/ 1 \%$ bovine serum albumin (BSA) (both from PAA) and used for a Ficoll gradient (Lymphoprep). The leukocyte layer was transferred to new tubes after centrifugation at $800 \times g$ for 30 minutes. Cells were washed three times with PBS/1\%BSA and re-suspended in RPMI-1640 medium supplemented with 10\% FCS, $1 \%$ penicillin/streptomycin and 2.5\% HEPES buffer solution (PAA).

Drugs and chemical reagents. Griseofulvin was purchased from Sigma-Aldrich (Steinheim, Germany) and tested at concentrations ranging from 0.1 to $200 \mu \mathrm{M}$ for $72 \mathrm{~h}$. For CCD-18Co cells, concentrations up to $400 \mu \mathrm{M}$ were tested.

3'3-Dihexyloxacarbocyanine iodide (DiOC6) and propidium iodide (PI) staining. Reduced mitochondrial transmembrane potential is known to occur late in the apoptotic process. We used DiOC6 staining and flow cytometry to assess the mitochondrial transmembrane potential. Therefore, $1 \times 10^{5}$ cells were plated in 3 $\mathrm{ml}$ medium in 6-well plates. Griseofulvin was dissolved in dimethyl sulfoxide (DMSO) (Invitrogen) and added to the medium at different concentrations for three days. Staining with DiOC6 for detecting viable cells and with PI, which binds to DNA in necrotic cells, was used for the apoptosis assay, measured by a fluorescence-activated cell sorter (FACS) (BD FACSCanto II; Becton Dickinson Biosciences, Franklin Lakes, NJ, USA). The medium containing drug-treated cells was transferred from each well into a glass tube. Then, cells were centrifuged at $800 \times g$ for 7 min, washed with phosphate buffered saline (PBS, pH 7.4) (RotiStock 10x, purchased from CarlRoth, Karlsruhe, Germany) and stained after repeated centrifugation by adding $500 \mu \mathrm{l}$ staining solution (RPMI-1640, 0.5\% bovine serum albumin (BSA), $80 \mathrm{nM}$ DiOC6) for $15 \mathrm{~min}$ at $37^{\circ} \mathrm{C}$. After another washing step with $\mathrm{PBS} / 1 \% \mathrm{BSA}$, cells were re-suspended in $500 \mu \mathrm{PBS} / 1 \%$ BSA. FACS analysis was performed immediately after the addition of 5 $\mu l$ PI solution $(100 \mu \mathrm{g} / \mathrm{ml})$ with a BD FACSCanto II (Becton Dickinson Biosciences) flow cytometer. Approximately 10,000 counts were made for each sample. In this assay, viable cells show high fluorescence intensity for DiOC6 and a low fluorescence for PI. Necrotic cells fluoresce in an opposite manner, with high intensity for PI and a low intensity for DiOC6. Early apoptotic cells show low fluorescence for both DiOC6 and PI. Cells with high fluorescence intensity for both DiOC6 and PI correspond either to late apoptotic cells as apoptotic bodies or debris.
Table I. Half-maximal inhibitory concentration $\left(I C_{50}\right)$ of griseofulvin for human lymphoma, human and murine multiple myeloma, murine leukemia and control cell lines. CCD-18Co cells and peripheral blood lymphocytes (PBLs) served as controls. A total of $1 \times 10^{5}$ cells were cultured under different concentrations of griseofulvin for $72 \mathrm{~h}$. Cell viability and apoptosis was measured by 3'3-Dihexyloxacarbocyanine iodide (DiOC6) and propidium iodide (PI) staining in flow cytometry. CCD-18Co cells were investigated by the 3-(4,5-dimethylthiazol-2-yl) 2,5-diphenyltetrazolium-bromide (MTT) assay. Results represent the mean of data from three independent experiments each.

$$
\mathrm{IC}_{50}(\mu \mathrm{M})
$$

Cell line Griseofulvin

\begin{tabular}{lc}
\hline KMS 18 & $9 \mu \mathrm{M}$ \\
OPM-2 & $45 \mu \mathrm{M}$ \\
RPMI-8226 & $26 \mu \mathrm{M}$ \\
U-266 & $18 \mu \mathrm{M}$ \\
MPC-11 & $44 \mu \mathrm{M}$ \\
Primary CLL cells & $80 \mu \mathrm{M}$ \\
Raji & $33 \mu \mathrm{M}$ \\
RAW 264,7 & $28 \mu \mathrm{M}$ \\
Oci Ly 8 Lam 53 & $30 \mu \mathrm{M}$ \\
SU DHL 4 & $22 \mu \mathrm{M}$ \\
CCD-18Co & $>400 \mu \mathrm{M}$ \\
PBL & $180 \mu \mathrm{M}$ \\
\hline
\end{tabular}

Cell viability assay with 3-(4,5-dimethylthiazol-2-yl)-2,5diphenyltetrazolium-bromide (MTT). The efficacy of griseofulvin in CCD-18Co cells was determined by cell viability in MTT assay. Viable cells convert the yellow MTT (Sigma Aldrich) into purple formazan when taken-up into mitochondria. Previously, cells were plated at $1 \times 10^{4}$ well/ $100 \mu \mathrm{l}$ in 96 -well plates and left to adhere overnight in the incubator. Twenty-four $h$ later media were removed and renewed containing various concentrations of griseofulvin. After $69 \mathrm{~h}, 1 \mu \mathrm{l} \mathrm{MTT}(5 \mathrm{mg} / \mathrm{ml})$ was added to each well and incubated for another 3-h period. Then, $80 \mu \mathrm{l}$ of the media were removed and $50 \mu \mathrm{l}$ of acidified isopropanol was added for cell lysis. After shaking for $10 \mathrm{~min}$, the amount of formazan was measured at $565 \mathrm{nM}$. The measured amount of formazan in treated cells was compared to untreated cells

Statistical analysis. Values are given as mean \pm standard deviation (SD). At least three separate and independent experiments were performed with each cell line. Paired, two-tailed Student's $t$-test was used for statistical analysis. A $p$-value less than 0.05 was considered significant.

\section{Results}

Titration of griseofulvin. The mean $50 \%$ inhibitory concentration $\left(\mathrm{IC}_{50}\right)$ after $72 \mathrm{~h}$ was calculated following titration. Griseofulvin concentrations leading to a significant decrease in viability of all tested myeloma and lymphoma cells were, therefore, determined. PBLs and CCD-18Co colonic fibroblasts served as healthy controls. All, except CCD-18Co, cells were investigated by DiOC6 and PI staining 


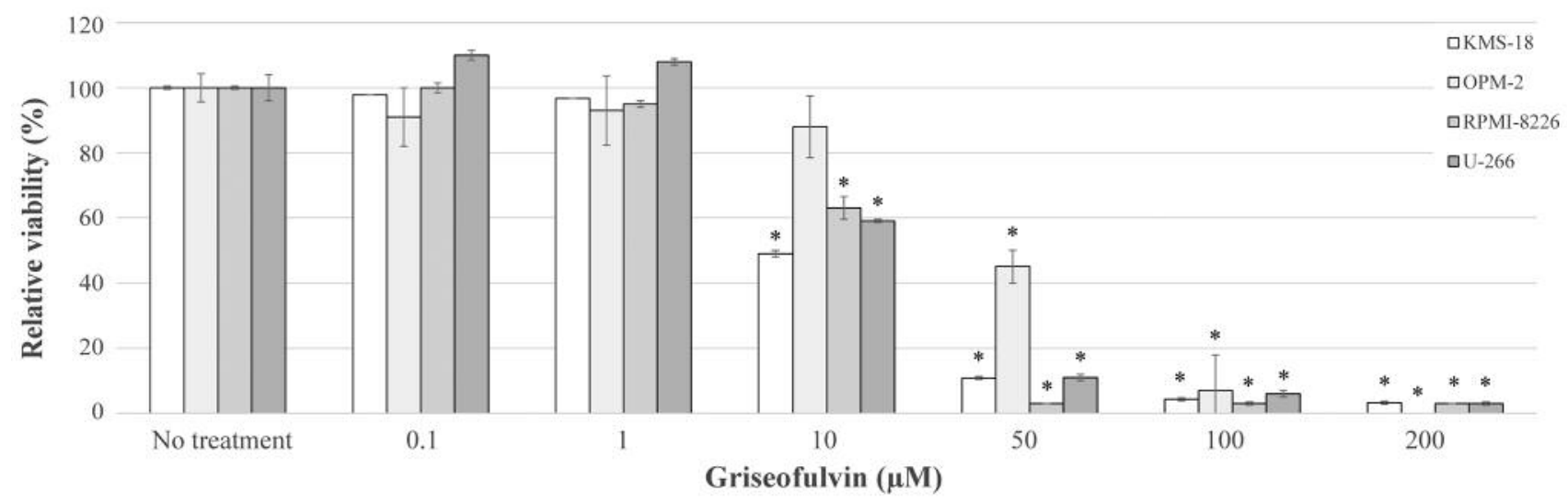

Figure 1. Effect of griseofulvin on viability of KMS-18, OPM-2, RPMI-8226 and U-266 human myeloma cells. Cells were cultured with griseofulvin for $72 \mathrm{~h}$. Cell viability and apoptosis was measured by 3'3-Dihexyloxacarbocyanine iodide (DiOC6) and propidium iodide (PI) staining in flow cytometry. Results represent data from three independent experiments. Data are shown as the mean $\pm S D . * p<0.05$ compared to untreated cells.

in flow cytometry. CCD-18Co cells were investigated by MTT. IC $_{50}$ values of griseofulvin employed after $72 \mathrm{~h}$ of incubation are given in Table I.

Effect of griseofulvin on viability of human myeloma cells. The viability of all investigated myeloma cells decreased in a concentration-dependent manner following the addition of griseofulvin. Low concentrations, starting from $10 \mu \mathrm{M}$, were required for a significant apoptosis induction in most human myeloma cells except OPM-2 cells, which tolerated doses up to $50 \mu \mathrm{M}$ without a significant decline in viability. Results are shown in Figure 1. Figure 2 (Panel A and B) shows the corresponding flow cytometry results.

Effect of griseofulvin on viability of human lymphoma cells. Exposure to griseofulvin also significantly decreased lymphoma cell viability in all tested cell lines. The $\mathrm{IC}_{50}$ of Raji, SU-DHL-4 and Oci Ly 8 Lam 53 was attained after treatment with $33 \mu \mathrm{M}, 22 \mu \mathrm{M}$ and $30 \mu \mathrm{M}$, respectively; a significant induction of apoptosis was registered, comparably with myeloma cells, at a griseofulvin concentration of $10 \mu \mathrm{M}$. Primary CLL cells were least susceptible to the toxicity of griseofulvin with an $\mathrm{IC}_{50}$ of $80 \mu \mathrm{M}$. Figure 3 presents the respective results. Figure 2 (Panel C) presents the corresponding flow cytometry results.

Effect of griseofulvin on viability of murine cells. The effects of griseofulvin treatment in human myeloma and lymphoma cells were also reproducible in murine myeloma and leukemia monocyte macrophage cells. Required griseofulvin concentrations for a significant decrease of viability in RAW 264.7 cells were comparable to those for human myeloma and lymphoma cells and slightly higher in MPC-11 cells with an $\mathrm{IC}_{50}$ of $28 \mu \mathrm{M}$ and $41 \mu \mathrm{M}$, respectively. Results are given in Figure 4.
Effect of griseofulvin on viability of healthy controls. We chose CCD-18Co colon fibroblasts and PBLs in order to analyze the toxicity of griseofulvin towards healthy stroma cells and lymphocytes, respectively. CCD18-Co cells and PBLs tolerated higher concentrations of griseofulvin compared to myeloma and lymphoma cell lines tested. Results are shown in Figure 5.

\section{Discussion}

MM represents a systemic malignant neoplasm caused by degenerated plasma cells, mainly due to frequent gene mutations and/or chromosomal translocations (30). Today's therapy schedules are built upon a primary initiated highdose chemotherapy followed by facultative hematopoietic stem cell transplantation (32-35). Recent therapy innovations enriched our therapeutic repertoire and led to both increased patient survival and improved quality of life. However, up to now, most MM patients remain incurable when solely treated with chemotherapy $(3,36,37)$.

Meanwhile, targeting tumor-specific signaling pathways promoting tumor differentiation and proliferation represents an established therapeutic approach in cancer research and treatment. As a promising example of abrogated signaling pathways, targeting canonical Wnt signaling might, thus, play a pivotal role for treatment of MM (10-14). Development and propagation of MM cells is, inter alia, dependent on the bone marrow microenvironment. Bone marrow stromal cells were shown to provide Wnt ligands encouraging an exaggerated proliferation of MM cells (37-39). The inhibition of $\mathrm{Wnt} / \beta$ catenin signaling, in return, retards MM growth as evidenced by numerous in vitro and in vivo studies (40).

Our laboratory recently revealed several drugs as potent inducers of apoptosis in lymphoma and myeloma cells in vitro and partially proved in vivo efficacy in subsequent animal 
A

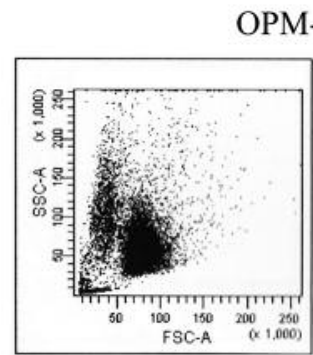

B

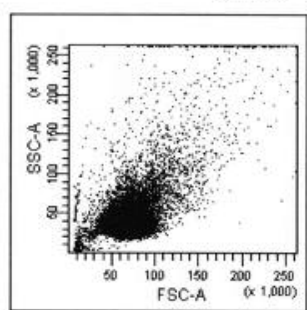

C

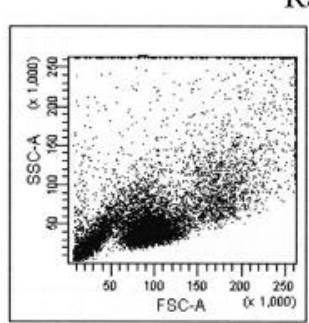

Raji + DMSO
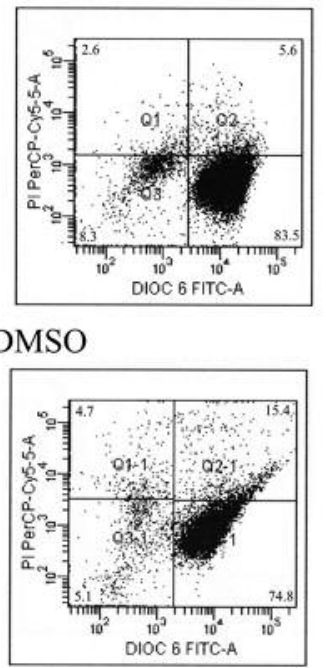

OPM-2 + Griseofulvin

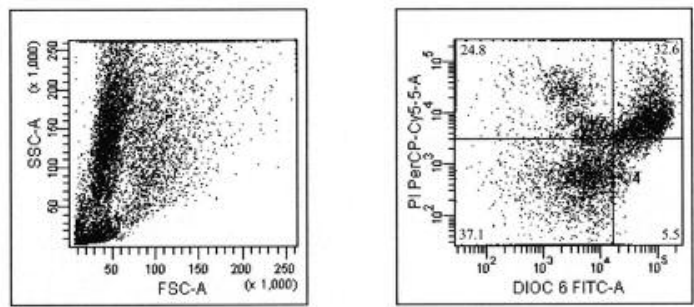

KMS-18 + Griseofulvin
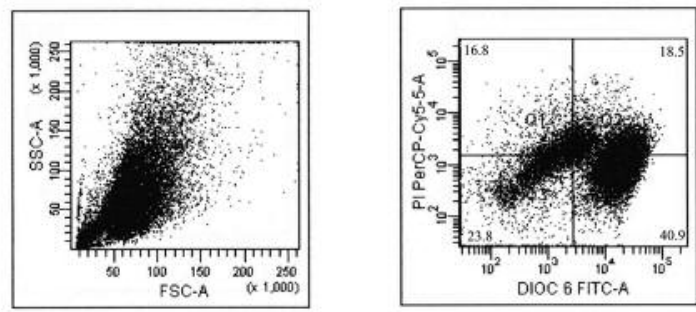

Raji + Griseofulvin
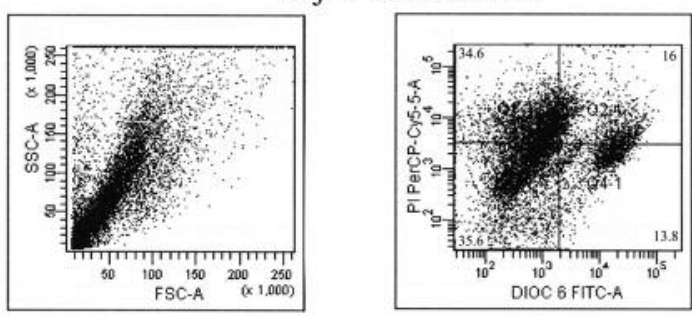

Figure 2. Exemplary results generated by flow cytometry. Within the quarters, the relative number of cells is given in percentages. (A) OPM-2 cells before and after treatment with $100 \mu M$ griseofulvin. (B) KMS-18 cells before and after treatment with $10 \mu M$ griseofulvin. (C) Raji cells before and after treatment with $50 \mu \mathrm{M}$ griseofulvin. Cells were treated with griseofulvin at different concentrations. Flow cytometry was performed seventytwo hours after incubation.

studies. Four of these drugs were already shown to inhibit the Wnt pathway through targeting either $\beta$-catenin itself or its downstream factors $(16-26,40,41)$. Owing to their chemical relationship to well-documented Wnt-inhibitors, such an inhibitory potential is also conceivable for the remaining agents.

Griseofulvin is an orally active antifungal drug, first isolated from Penicillium griseofulvum in 1939, used for the treatment of several dermatophytoses (39). Its mechanism of action was attributed to a selective inhibition of microtubule depolymerization and induction of abnormal cell mitosis by blocking at the $\mathrm{G}_{2} / \mathrm{M}$ phase. These antiproliferative and antimitotic effects are merely weak in mammalian cells following the intake of sufficient fungicidal doses (42-44).

Griseofulvin-promoted abnormal microtubule stabilization was shown to induce a cascade of events leading to apoptosis. In HT 29 colorectal adenocarcinoma cells, low doses of 10 $\mu \mathrm{M}$ induced apoptosis, whereas higher doses of $>20 \mu \mathrm{M}$ initiated significant $\mathrm{G}_{2} / \mathrm{M}$ arrest. Higher doses $(>20 \mu \mathrm{M})$ caused an increase of cell death and $\mathrm{G}_{2} / \mathrm{M}$ mitotic arrest. Griseofulvin-induced $\mathrm{G}_{2} / \mathrm{M}$ arrest was not solely attributed to the induction of abnormal mitotic spindle formation but also to the elevation of cyclin B1/cdc2 kinase activity and the down-regulation of myelin transcription factor-1 (myt-1) protein expression. Additionally, caspase 3 activation and Bcell lymphoma 2 (Bcl-2) hyperphosphorylation were supposed to be the mechanisms of griseofulvin-induced apoptosis (44). Another study demonstrated that very high concentrations of griseofulvin $(>100 \mu \mathrm{M})$ were required to inhibit microtubule polymerization in HeLa cervical cancer cells, albeit much lower drug concentrations (1-20 $\mu \mathrm{M})$ effectively suppressed the dynamic instability of microtubules; the authors concluded that the primary mechanism of action by which griseofulvin inhibits mitosis in human cells is by suppressing spindle microtubules dynamics similar to other antimitotic drugs as vinca alkaloids and taxanes (44). Besides that, treatment of adrenocortical cancer cells with a griseofulvin concentration of $40 \mu \mathrm{M}$ for $24 \mathrm{~h}$ resulted in a significant induction of apoptosis, as shown by caspase $3 / 7$ cleavage (46).

Interestingly, in HL-60 leukemia cells, the activation of the nuclear factor-kappa B (NF-kB) pathway, as well as the activation of c-Jun N-terminal kinases (JNKs), significantly promoted the phosphorylation of Bcl-2 resulting in $\mathrm{G}_{2} / \mathrm{M}$ 


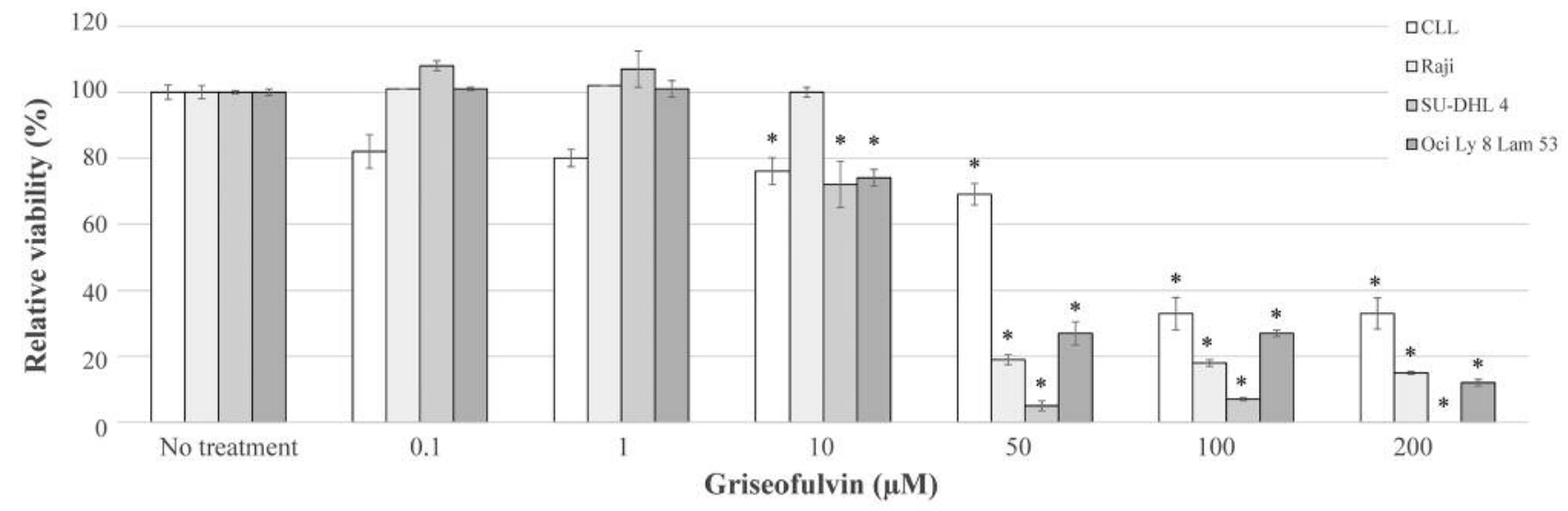

Figure 3. Effect of griseofulvin on viability of primary CLL, Raji, SU DHL 4 and Oci Ly 8 Lam 53 human lymphoma cells. Cells were cultured with griseofulvin for $72 \mathrm{~h}$. Cell viability and apoptosis was measured by 3'3-Dihexyloxacarbocyanine iodide (DiOC6) and propidium iodide (PI) staining in flow cytometry. Results represent data from three separate experiments each. Data are shown as mean $\pm S D . * p<0.05$ compared to untreated cells.

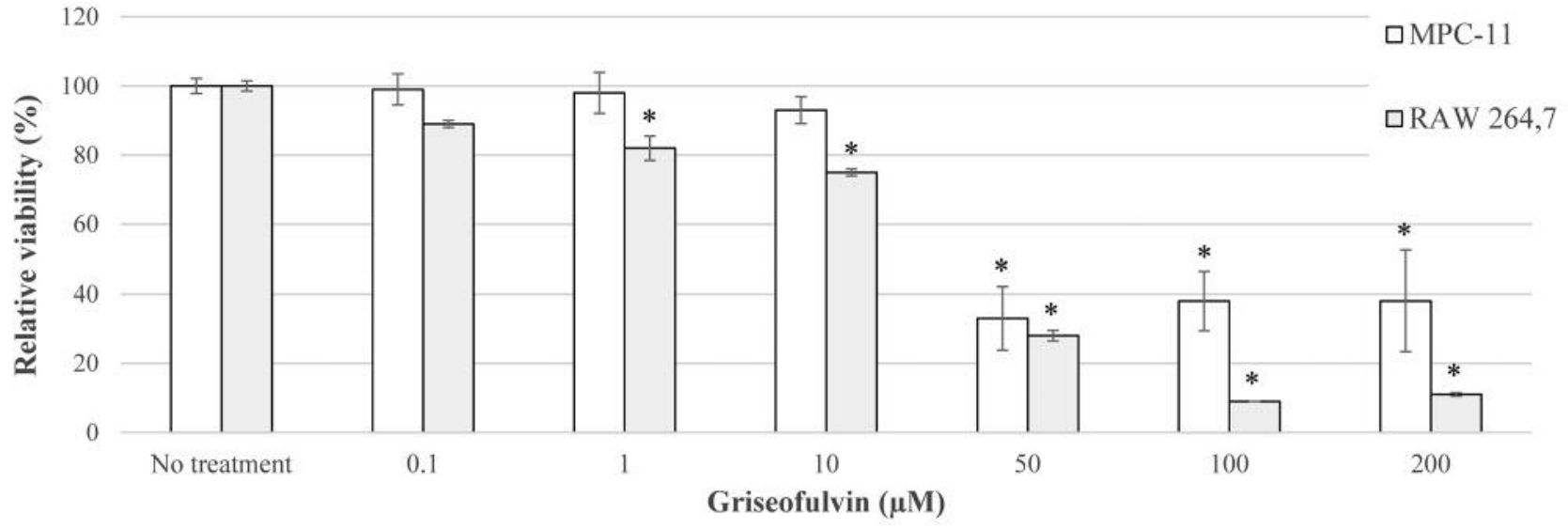

Figure 4. Effect of griseofulvin on viability of MPC-11 and RAW 264.7 murine myeloma and leukemia cells, respectively. Cells were cultured with griseofulvin for $72 \mathrm{~h}$. Cell viability and apoptosis was measured by 3'3-Dihexyloxacarbocyanine iodide (DiOC6) and propidium iodide (PI) staining in flow cytometry. Results represent data from three separate experiments each. Data are shown as mean $\pm S D .{ }^{*} p<0.05$ compared to untreated cells.

cell-cycle arrest and induction of apoptosis (47); this is of major importance since the majority of the above mentioned signaling pathways and molecules also interfere with the Wnt pathway, particularly within the scope of hematological neoplasms. Despite those initial results, the effect of griseofulvin on both MM and lymphoma was solely addressed in vivo by a recent study of our workgroup using a murine myeloma cell model in which we could demonstrate prolonged survival and reduced tumor growth in myelomabearing mice (31), whilst in vitro data were lacking.

Our presented in vitro data indicate that griseofulvin affects the growth of multiple myeloma and lymphoma since it significantly reduced the viability of all tested myeloma and lymphoma cell lines by apoptosis induction due to reduced mitochondrial membrane potentials. Thereby, both human and murine cells were equally affected in a dose- dependent manner. Doses of approximately $10 \mu \mathrm{M}$ significantly decreased cell viability in most myeloma and lymphoma cell lines tested. Interestingly, CCD-18Co colonic fibroblasts and PBLs, serving as healthy controls, tolerated higher drug concentrations. These data and the given safety profile of griseofulvin, as a commonly used anti-fungicidal drug, emphasize its favorable tolerability.

Due to its influence on Wnt-associated signaling molecules in leukemia and other malignancies, griseofulvin might also interfere with signaling molecules embedded in the Wnt and associated signaling pathways in lymphoma and multiple myeloma. Griseofulvin demonstrated a significant cytotoxic potential towards both MM and lymphoma cells by apoptosis induction and slightly decreased the viability of healthy controls. Hence, advanced studies investigating its potential as novel therapeutic drug for MM and lymphoma are warranted. 


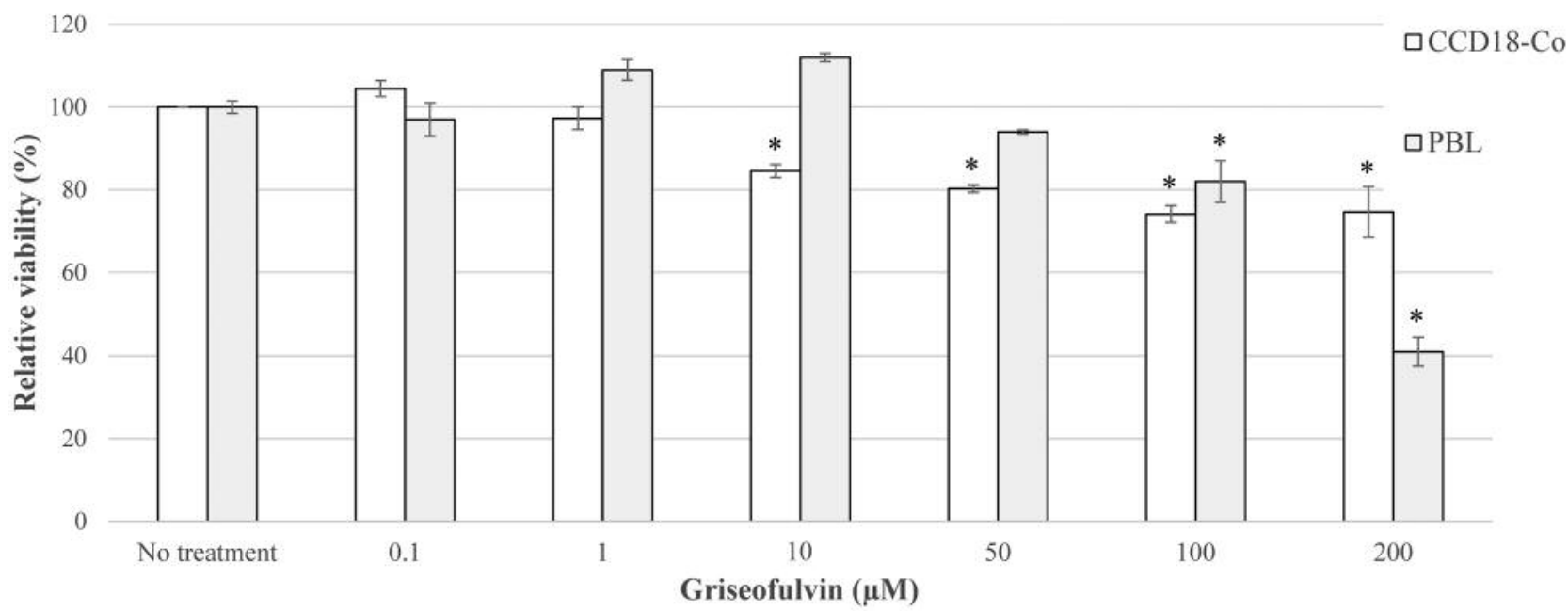

Figure 5. Effect of griseofulvin on viability of CCD-18Co cells and peripheral blood lymphocytes (PBLs) that served as healthy controls. Cells were cultured with griseofulvin for $72 \mathrm{~h}$. For CCD-18Co cells, viability was measured by the 3-(4,5-dimethylthiazol-2-yl)-2,5-diphenyltetrazolium-bromide (MTT) assay. For PBLs, viability and apoptosis was measured by 3'3-Dihexyloxacarbocyanine iodide (DiOC6) and propidium iodide (PI) staining in flow cytometry. Results represent data from three separate experiments each. Data are shown as mean $\pm S D$. * $p<0.05$ compared to untreated cells.

\section{References}

1 Palumbo A and Anderson K: Multiple myeloma. N Engl J Med 364: 1046-1060, 2011.

2 Howlader N, Noone AM, Krapcho M, Garshell J, Neyman N, Altekruse SF, Kosary CL, Yu M, Ruhl J, Tatalovich Z, Cho H, Mariotto A, Lewis DR, Chen HS, Feuer EJ and Cronin KA: SEER Cancer Statistics Review, 1975-2010. National Cancer Institute. Bethesda, MD, based on November 2012 SEER data submission, posted to the SEER website, April 2013.

3 Schmeel FC, Schmeel LC, Gast SM and Schmidt-Wolf IG: Adoptive immunotherapy strategies with cytokine-induced killer (CIK) cells in the treatment of hematological malignancies. Int J Mol Sci 15: 14632-14648, 2014.

4 Schmeel LC, Schmeel FC, Coch C and Schmidt-Wolf IG: Cytokine-induced killer (CIK) cells in cancer immunotherapy: Report of the international registry on CIK cells (IRCC). J Cancer Res Clin Oncol 141: 839-849, 2015.

5 Clevers $\mathrm{H}$ : Wnt/beta-catenin signaling in development and disease. Cell 127: 469-480, 2006.

6 Moon RT, Kohn AD, De Ferrari GV and Kaykas A: WNT and beta-catenin signalling: Diseases and therapies. Nat Rev Genet 5: 691-701, 2004.

7 Nusse R: Wnt signaling in disease and in development. Cell Res 15: 28-32, 2005.

8 Polakis P: Wnt signaling and cancer. Genes Dev 14: 1837-1851, 2000.

9 Willert $\mathrm{K}$ and Jones KA. Wnt signaling: Is the party in the nucleus? Genes Dev 20: 1394-1404, 2006.

10 Dutta-Simmons J, Zhang Y, Gorgun G, Gatt M, Mani M, Hideshima T, Takada K, Carlson NE, Carrasco DE, Tai YT, Raje $\mathrm{N}$, Letai AG, Anderson KC and Carrasco D: Aurora kinase A is a target of $\mathrm{Wnt} /$ beta-catenin involved in multiple myeloma disease progression. Blood 114: 2699-2708, 2009.
11 Qiang YW, Endo Y, Rubin JS and Rudikoff S: Wnt signaling in B-cell neoplasia. Oncogene 22: 1536-1545, 2003.

12 Sukhdeo K, Mani M, Zhang Y, Dutta J, Yasui H, Rooney MD, Carrasco DE, Zheng M, He H, Tai YT, Mitsiades C, Anderson KC and Carrasco DR: Targeting the beta-catenin/TCF transcriptional complex in the treatment of multiple myeloma. Proc Natl Acad Sci USA 104: 7516-7521, 2007.

13 Derksen PW, Tjin E, Meijer HP, Klok MD, MacGillavry HD, van Oers MH, Lokhorst HM, Bloem AC, Clevers H, Nusse R, van der Neut R, Spaargaren M and Pals ST: Illegitimate WNT signaling promotes proliferation of multiple myeloma cells. Proc Natl Acad Sci USA 101: 6122-6127, 2004.

14 Chapman MA, Lawrence MS, Keats JJ, Cibulskis K, Sougnez C, Schinzel AC, Harview CL, Brunet JP, Ahmann GJ, Adli M, Anderson KC, Ardlie KG, Auclair D, Baker A, Bergsagel PL, Bernstein BE, Drier Y, Fonseca R, Gabriel SB, Hofmeister CC, Jagannath S, Jakubowiak AJ, Krishnan A, Levy J, Liefeld T, Lonial S, Mahan S, Mfuko B, Monti S, Perkins LM, Onofrio R, Pugh TJ, Rajkumar SV, Ramos AH, Siegel DS, Sivachenko A, Stewart AK, Trudel S, Vij R, Voet D, Winckler W, Zimmerman T, Carpten J, Trent J, Hahn WC, Garraway LA, Meyerson M, Lander ES, Getz G and Golub TR: Initial genome sequencing and analysis of multiple myeloma. Nature 471: 467-472, 2011.

15 Ashihara E, Kawata E, Nakagawa Y, Shimazaski C, Kuroda J, Taniguchi K, Uchiyama H, Tanaka R, Yokota A, Takeuchi M, Kamitsuji Y, Inaba T, Taniwaki M, Kimura S and Maekawa T: Beta-catenin small interfering RNA successfully suppressed progression of multiple myeloma in a mouse model. Clin Cancer Res 15: 2731-2738, 2009.

16 Kim Y, Schmidt M, Endo T, Lu D, Carson D and Schmidt-Wolf IG: Targeting the Wnt/beta-catenin pathway with the antifungal agent ciclopirox olamine in a murine myeloma model. In Vivo 25(6): 887-893, 2011. 
17 Schmeel LC, Schmeel FC, Kim Y, Endo T, Lu D and SchmidtWolf IG: Targeting the Wnt/beta-catenin pathway in multiple myeloma. Anticancer Res 33(11): 4719-4726, 2013.

18 Schmidt M, Sievers E, Endo T, Lu D, Carson D and SchmidtWolf IG: Targeting Wnt pathway in lymphoma and myeloma cells. Br J Haematol 144(5): 796-798, 2009.

19 Kim Y, Alpmann P, Blaum-Feder S, Krämer S, Endo T, Lu D, Carson D and Schmidt-Wolf IG: Increased in vivo efficacy of lenalidomide by addition of piroctone olamine. In Vivo 25(1): 99-103, 2011.

20 Koller CM, Kim Y and Schmidt-Wolf IG: Targeting renal cancer with a combination of WNT inhibitors and a bi-functional peptide. Anticancer Res 33(6): 2435-2440, 2013.

21 von Schulz-Hausmann SA, Schmeel LC, Schmeel FC and Schmidt-Wolf IG: Targeting the Wnt/beta-catenin pathway in renal cell carcinoma. Anticancer Res 34(8): 4101-4108, 2014.

22 Schmidt M, Kim Y, Gast SM, Endo T, Lu D, Carson D and Schmidt-Wolf IG: Increased in vivo efficacy of lenalidomide and thalidomide by addition of ethacrynic acid. In Vivo 25(3): 325333, 2011.

23 Kim Y, Reifenberger G, Lu D, Endo T, Carson DA, Gast SM, Meschenmoser K, Nowak M and Schmidt-Wolf IG: Influencing the Wnt signaling pathway in multiple myeloma. Anticancer Res 31(2): 725-730, 2011.

24 Lu D, Liu JX, Endo T, Zhou H, Yao S, Willert K, Schmidt-Wolf IG, Kipps TJ and Carson DA: Ethacrynic acid exhibits selective toxicity to chronic lymphocytic leukemia cells by inhibition of the Wnt/beta-catenin pathway. PLoS One 4(12): e8294, 2009.

25 Schmeel FC, Schmeel LC, Kim Y and Schmidt-Wolf IG: Piceatannol exhibits selective toxicity to multiple myeloma cells and influences the Wnt/ beta-catenin pathway. Hematol Oncol 32: 197-204, 2014.

26 Wall I and Schmidt-Wolf IG: Effect of Wnt inhibitors in pancreatic cancer. Anticancer Res 34(10): 5375-5380, 2014.

27 Schmeel LC, Schmeel FC, Kim Y, Blaum-Feder S, Endo T and Schmidt-Wolf IG: In vitro efficacy of cinnarizine against lymphoma and multiple myeloma. Anticancer Res 35(2): 835-841, 2015.

28 Schmeel LC, Schmeel FC, Kim Y, Blaum-Feder S, Endo T and Schmidt-Wolf IG: Flunarizine exhibits in vitro efficacy against lymphoma and multiple myeloma cells. Anticancer Res 35(3): 1369-1376, 2015.

29 Schmeel LC, Schmeel FC, Blaum-Feder S and Schmidt-Wolf IG: In vitro efficacy of naftifine against lymphoma and multiple myeloma. Anticancer Res 35: 5921-5926, 2015.

30 Schmeel LC, Schmeel FC and Schmidt-Wolf IG: Clofibrate demonstrates efficacy in in vitro treatment of lymphoma and multiple myeloma. Anticancer Res 36: 3395-4000, 2016

31 Kim Y, Alpmann P, Blaum-Feder S, Krämer S, Endo T, Lu D, Carson D and Schmidt-Wolf IG: In vivo efficacy of griseofulvin against multiple myeloma. Leuk Res 35: 1070-1073, 2011.

32 Kuehl WM and Bergsagel PL: Multiple myeloma: evolving genetic events and host interactions. Nat Rev Cancer 2: 175-187, 2002.

33 Harousseau JL and Moreau P: Autologous hematopoietic stemcell transplantation for multiple myeloma. N Engl J Med 360: 2645-2654, 2009

34 Moreau P, Hullin C, Garban F, Yakoub-Agha I, Benboubker L, Attal M, Marit G, Fuzibet JG, Doyen C, Voillat L, Berthou C, Ketterer N, Casassus P, Monconduit M, Michallet M, Najman A, Sotto JJ, Bataille R, Harousseau JL; Intergroupe Francophone du
Myélome group: Tandem autologous stem cell transplantation in high-risk de novo multiple myeloma: Final results of the prospective and randomized IFM 99-04 protocol. Blood 107(1): 397-403, 2006.

35 Rosiñol L, Pérez-Simón JA, Sureda A, de la Rubia J, de Arriba F, Lahuerta JJ, González JD, Díaz-Mediavilla J, Hernández B, García-Frade J, Carrera D, León A, Hernández M, Abellán PF, Bergua JM, San Miguel J, Bladé J; Programa para el Estudio y la Terapéutica de las Hemopatías Malignas y Grupo Español de Mieloma (PETHEMA/GEM): A prospective PETHEMA study of tandem autologous transplantation versus autograft followed by reduced-intensity conditioning allogeneic transplantation in newly diagnosed multiple myeloma. Blood 112(9): 3591-3593, 2008.

36 Bringhen S, Avonto I, Magarotto V, Boccadoro M and Palumbo A: Investigational treatments for multiple myeloma. Expert Opin Investig Drugs 15: 1565-1582, 2006.

37 Hideshima T, Mitsiades C, Tonon G, Richardson PG and Anderson KC: Understanding multiple myeloma pathogenesis in the bone marrow to identify new therapeutic targets. Nat Rev Cancer 7: 585-598, 2007.

38 Fowler JA, Mundy GR, Lwin ST and Edwards CM: Bone marrow stromal cells create a permissive microenvironment for myeloma development: A new stromal role for Wnt inhibitor Dkk1. Cancer Res 72(9): 2183-2189, 2012.

39 Kocemba KA, Groen RW, van Andel H, Kersten MJ, Mahtouk $\mathrm{K}$, Spaargaren $\mathrm{M}$ and Pals ST: Transcriptional silencing of the Wnt-antagonist DKK1 by promoter methylation is associated with enhanced Wnt signaling in advanced multiple myeloma. PLoS One 7(2): e30359, 2012.

40 Kim Y, Gast SM, Endo T, Lu D, Carson D and Schmidt-Wolf IG: In vivo efficacy of the diuretic agent ethacrynic acid against multiple myeloma. Leuk Res 36(5): 598-600, 2012.

41 Messina CS, Weiher $\mathrm{H}$ and Schmidt-Wolf IG: Targeting prostate cancer with a combination of WNT inhibitors and a bi-functional peptide. Anticancer Res 37: 555-559, 2017.

42 De Carli L and Larizza L: Griseofulvin. Mutat Res 195: 91-126, 1988.

43 Chan YC and Friedlander SF: New treatments for tinea capitis. Curr Opin Infect Dis 17: 97-103, 2004.

44 Panda D, Rathinasamy K, Santra MK and Wilson L: Kinetic suppression of microtubule dynamic instability by griseofulvin: Implications for its possible use in the treatment of cancer. Proc Natl Acad Sci USA 102: 9878-9883, 2005.

45 Ho YS, Duh JS, Jeng JH, Wang YJ, Liang YC, Lin CH, Tseng $\mathrm{CJ}, \mathrm{Yu} \mathrm{CF}$, Chen RJ and Lin JK: Griseofulvin potentiates antitumorigenesis effects of nocodazole through induction of apoptosis and $\mathrm{G}_{2} / \mathrm{M}$ cell cycle arrest in human colorectal cancer cells. Int J Cancer 91(3): 393-401, 2001.

46 Bramann EL, Willenberg HS, Hildebrandt B, Müller-Mattheis V, Schott M, Scherbaum WA and Haase M: Griseofulvin inhibits the growth of adrenocortical cancer cells in vitro. Horm Metab Res 45(4): 297-300, 2013.

47 Uen YH, Liu DZ, Weng MS, Ho YS and Lin SY: NF-kappaB pathway is involved in griseofulvin-induced $\mathrm{G}_{2} / \mathrm{M}$ arrest and apoptosis in HL-60 cells. J Cell Biochem 101(5): 1165-1175, 2007.

Received March 15, 2017

Revised March 27, 2017

Accepted March 27, 2017 